Ljiljana Matavulj ${ }^{1}$

University Union "Nikola Tesla"

Faculty of Business Studies and Law, Belgrade
ORIGINAL SCIENTIFIC ARTICLE

DOI: $10.5937 /$ ekonomika2101059M

Received: November, 01. 2020.

Accepted: December 02. 2020.

\title{
CALCULATION OF TRANSFER PRICES: THEORETICAL AND PRACTICAL IMPLICATIONS ON THE RESULT
}

\begin{abstract}
With the increase in the volume of international exchange and the globalization of multinational companies, problems of transfer pricing control in transactions between affiliates and their alignment with the "arm's length" pricing principle are growing. A proper calculation of transfer pricing affects the amount of taxable income and provides a basis for checking whether in this way profit is "extracted" to other tax jurisdictions. The international transfer pricing guidelines have recommended several methods for calculating transfer prices, depending on the circumstances of the case, including several recommended parameters relevant to the calculation. Also, if the Cost Plus Margin method and Transactional Net Margin (TNM) method can be applied in an equally reliable manner, the recommendation is Cost Plus Margin. Many countries have accepted the international guidelines and incorporated them into their national regulations. However, in the absence of a serious analysis of the effects in practice, the possibility of deviations in the calculation of results was also accepted. If these results are ultimately the amount of tax paid or not paid in a country, then it is understandable why these deviations deserve special attention. The main hypothesis in this paper is that when both methods are applicable, the Cost Plus Margin method should not always be favored, as effects that should be prevented may occur. Due to the circumstances of the case, a proper calculation can be very debatable if certain parameters change a minimum. The paper discusses deviations of the transfer price from the "arm's length" principle when both methods are equally acceptable, and with minimum changes to two parameters: the size of the sample of comparable companies and the observation period. All this has been tested on the example of a multinational company from one of the developed countries in Europe, which has a related entity in one of Europe's developing countries. The tested party is a related entity as a developing country taxpayer. In the implication generally there are many problems and dilemmas that need to be overcome in the relationships between the party calculating the transfer prices, the companies themselves, and the tax administrations. It is very significant from which aspect the calculation is managed. If the aspect of the company is favored, then the best option is the one where the company will pay the lowest tax. However, if the tax administration is already authorized to request a change in the calculation, then it will work in the interest of the state, and the most unfavorable option for the corporation may be obtained by changing some of the parameters used. Both would be formally acceptable, but the tax amount would not be the same. Possible scenarios in the test case showed
\end{abstract}

${ }^{1}$ ljiljana.matavulj@fpsp.edu.rs, ORCID ID 0002-0724-2729 
that internationally recognized recommendations regarding method selection have weaknesses because they do not include all the parameters of the methodology, which significantly affects the end result. In a situation where the observation timeframe is flexible and no minimum sample size of comparable companies is defined, there is practically space to manipulate the final result. In order to avoid ambiguity and various forms of manipulation in the transfer pricing calculation, it is necessary to further specify international guidelines for the development of transfer pricing in the domain of time and size of the sample. Additionally, the taxpayer's obligation to apply transfer price calculations should be introduced for all methods that respond to the circumstances of their case, and not just one of them. This generally can be overcome either by changing the guidelines or by defining rules in greater detail at the level of the depends on multiple parameters, both those defined in theory and those that are not national legislation of each state, whilst improving the professional capacity of the tax administration to control transfer pricing.

Purpose - The importance of properly calculating transfer pricing is emphasized, which depends on multiple parameters, both those defined in theory and those that are not, but should be. International guidelines recommend several methods for calculating transfer pricing, and which one should be given priority if two of them are equally acceptable? If they are TNM and Cost Plus, the latter takes precedence. The purpose of the paper is to show that in practice this may not be the case, which is the basic hypothesis on which it is based.

Research design/method/approach - The paper first considers the existing international methodology for calculating transfer prices and then the issue of calculation in practice in the case of minimal deviation of two significant components of comparability: sample size and time dimension of parameters. All this will be tested on the example of a multinational company from one of the developed European countries, which has a related party in one of the developing countries in Europe. The test party is a related entity of a taxpayer in a developing country. Several calculation scenarios are given for case of the aforementioned changes, which give different tax amounts. If a developing country accepts (by including in national regulations) an international recommendation on the advantage of the Cost Plus method, it will have accepted that in practice it will in some cases charge a smaller tax.

Findings - The hypothesis was confirmed that the Cost Plus method should not always take precedence over the TNM method. A more detailed analysis of the different scenarios for the particular circumstances of the case gives wider opportunities to properly determine the basis for taxation but also to prevent the country's tax losses. An argument is also given for defining national regulations in more detail to avoid unwanted occurrences.

Practical implication - It is necessary to amend international guidelines and national tax regulations, as well as to increase the professional capacity of the tax administration in this area. This will increase the control of transfer pricing, as well as the "extraction" of profits from the country to other tax jurisdictions

Originality/Value - Theory and practice need to be more connected. Practical examples show that some changes need to be made in this area to more effectively 
prevent tax evasion. There are many objections to the existing concept of transfer pricing in literature, but no similar practical examples and studies are available to confirm deviations in the calculation as outlined in this paper.

Key words: Transfer prices, arm's length principle, transactional net margin method, cost plus gross margin method, taxable income.

JEL classification: K34, H26, O19, F61

\title{
ОБРАЧУН ТРАНСФЕРНИХ ЦЕНА - ТЕОРИЈСКЕ И ПРАКТИЧНЕ ИМПЛИКАЦИЈЕ НА РЕЗУЛТАТ
}

\begin{abstract}
Апстракт
Саповећањемобимамеђународнеразменеиглобализацијоммултинационалних компанија, расту проблеми контроле трансферних цена у трансакцијама између повезаних компанија и юихово усклађивање са иенама „ван дохвата руке“. Правилан обрачун трансферних иена утиче на износ опорезивог прихода и пружа основу за проверу да ли се профит на овај начин ,, извлачи “ у друге пореске јурисдикиије. Међународне смернице за трансферне цене препоручују неколико метода за израчунавање трансферних иена, у зависности од околности случаја, укључујући и неколико препоручених параметара релевантних за израчунавање. Такође, у случајевима када се метод „цена коштања плус маржа“ и метод „трансакциона нето маржа“ (ТНМ) могу применити на једнако поуздан начин, препорука је да се примени ,цена коштана плус маржа“. Многе земье су прихватиле међународне смернице и уградиле их у своје националне прописе. Међутим, у одсуству озбиљне анализе ефеката у пракси, на тај начин су се прихватиле и могућности за појаву девијација у резултатима обрачуна. Ако су ти резултати на крају висина пореза која се плаћа или не плаћа у некој земљи, онда је разумливо зашто ове девијащије заслужују посебну пажну. Главна хипотеза у овом раду је да када су оба метода примењива, не треба увек давати предност методу „цена коштања плус маржа“, јер могу да се појаве ефекти који су желели да се спрече. Управо у зависности од околности случаја, правилно израчунавање може бити веома дискутабилно чак и ако се неки параметри минимално промене. У раду су размотрена одступања трансферне цене од принщипа „ван дохвата руке“ када су оба метода пођеднако прихватљива и уз минималне измене у два параметра: величини узорка упоредивих компанија и периоду посматрања. Све ово тестирано је на примеру мултинационалне компаније из једне од развијених европских земаља, која има повезано лице у једној од европских земаља у развоју. Тестирана страна је повезано лице као порески обвезник земье у развоју. У примени генерално постоји пуно проблема и дилема које треба превазићи у односу између онога који израчунава трансферне цене, самих компанија и пореске управе. Веома је важно с ког аспекта се врии обрачун. Ако се преферира аспект предузећа, тада је најбоља опџија она за коју ће компанија платити најнижи порез. Међутим, ако пореска управа већ има право да затражи промену обрачуна, тада ће то радити у интерсу
\end{abstract}


државе, а најнеповољнија опиија за фирму може се добити променом неког од коришћених параметара. И једно и друго би било формално прихватљьво, али висина пореза не би била иста. Могући сиенарији у тестном случају показали су да међународно признате препоруке у избору метода имају слабости, јер не укључују све параметре саме методологије који значајно утичу на крајни резултат. У ситуацији када је временски период посматрања флексибилан и није дефинисана минимална величина узорка упоредивих компанија, практично је отворен простор за манипулацију коначним резултатом. Да би се избегле нејасноће и различити облици манипулачије у израчунавағу трансферних цена, потребно је даље прецизирати међународне смернице за развој трансферних иена у домену временске димензије и величине узорка. Поред тога, требало би обавезати пореског обвезника да изврии калкулащије трансферних ичена по свим методама које одговарају околностима његовог случаја, а не само једној од юих. Ово се генерално може превазићи или променом самих смерница или ближим дефинисањем правила на нивоу националног законодавства сваке државе, уз неопходност побољшања професионалне способности пореске управе за контролу трансферних иеена.

Сврха - Истакнут је значај правилног обрачуна трансферних изена, који зависи од вите параметара, како од оних дефинисаних у теорији, тако и од оних који то нису, а требало би да буду. Међународне смернице препоручују неколико метода за обрачун трансферних цена, као и којој од юих треба дати предност уколико су две од юих пођеднако прихватљиве. Уколико су то „ТНТ“ и „Цост плус“, предност има „Цост плус“. Сврха рада је да покаже да у пракси то не мора да буде тако, ито је и основна хипотеза од које се полази.

Дизајн/Методи/Приступ - У раду се најпре разматра расположива међународна методологија за обрачун трансферних цена а затим проблематика обрачуна у пракси у случају минималног одступаға две значајне компоненте упоредивости - величине узорка и временске димензије параметара. Све ово ће се тестирати на примеру мултинационалне компаније из једне од развијених европских земаља, која има повезано лице у једној од европских земаља у развоју. Тестирана страна је повезано лице као порески обвезник земье у развоју. Дато је више сценарија обрачуна у случају наведених промена по којима се добијају различити износи пореза. Уколико земља у развоју прихвати (укључивањем y националне прописе) међународну препоруку о предности метода “Цена коштања плус" - у пракси је прихватила да ће у неким случајевима наплатити мани порез.

Резултати - Потврђена је хипотеза да метод “Цена коштања плус” не треба увек да има предност у односу на метод “ТНТ”. Детаљнијом анализом различитих сценарија за конкретне околности случаја, добијају се шире могућности за правилно одређиваюе основе за опорезиване али и за спречавање одливања пореза из земье. Такође се добија и аргумент за детаљније дефинисање начионалних прописа како би се избегле појаве које су желеле да се спрече.

Практичне импликације - Непходно је допунити међународне смернице и националне прописе о опорезиваьу, као и повећати стручни капацитет пореске администраџије у овој области. Тиме ће се повећати и контрола обрачуна трансферних ичена, као и “извлачена" профита из земье у друге пореске 


\section{јурисдикичје.}

Оригиналност/Вредност - Теорија и пракса треба да буду више повезане. Практични примери показују да у овој области треба извриити одређене измене како би се ефикасније спречила пореска евазија. У литератури се износи доста замерки на постојећи конщепт обрачуна трансферних иена али нема доступних сличних практичних примера и студија који би потврдили одступања у обрачуну, на начин како је изложено у овом раду.

Кључне речи: Трансферне цене, иуене “ван дохвата руке”, метод трансакиионе нето марже, метод цена коштања плус бруто маржа”, опорезиви приход.

\section{Introduction}

At an era of accelerated expansion of the business activities of multinational companies in the markets of many countries, with different tax regulations, the problem that is constantly current is the correct calculation of transfer prices, i.e. the price that is formed in transactions between related parties (Elliot \& Emmanuel, 2002). Since taxpayers are required to disclose these transactions in tax balance sheets, this is an area where the possibility of avoiding payment of taxes between different tax jurisdictions is recognized at the international level (Bhata, 2009). Over the years, international rules have sought and perfected (OECD, 2011; UN Guidelines, 2013) principles for adjusting transfer prices, based on the "arm's length" principle.

Many countries have accepted international guidelines and incorporated them into their national regulations. However, in application there are always a number of problems and dilemmas that need to be overcome on the relationship between the one who calculates transfer prices, the companies themselves and the tax administrations. (Timms, 2013; De Robertis, 2018; Durst, 2010; Durst \& Culbertson, 2003). This is due to the fact that the amount of taxable income of a company that involves related parties in one or more countries depends on the result of the calculation itself. Accountability issues are further enhanced when an entity is in a developing country (Cooper, Fox, Loeprick \& Komal, 2016; Sikka, 2009; Suraj, 2017; Ostwal, 2009; UNCTAD, 2015). All these authors are critics of this concept. In essence, they all agree that because of its complexity, this concept is increasingly subject to manipulation, such as transferring part of the profits to tax jurisdictions with lower taxation rates. Legislation is one way to prevent such abuse (Jovanović, 2018).

In this paper the importance of properly calculating transfer pricing is emphasized. That depends on multiple parameters, both those defined in theory and those that are not, but should be. International guidelines recommend several methods for calculating transfer pricing. Which one should be given priority if two of them are equally acceptable? If they are TNM and Cost Plus, the latter takes precedence. The purpose of the paper is to show that in practice this may not be the case, which is the basic hypothesis on which it is based. 


\section{Theoretical backgrounds}

In the extensive literature and the aforementioned guidelines, the basic concepts and essence of the concept are clear. The "arm's length" principle is an international standard for the application of transfer pricing rules. When unrelated parties perform transactions, the conditions of their commercial and financial relations are usually the result of the market. All conditions that are in line with market conditions are considered to be in accordance with the "arm's length" principle. The use of the "arm's length" principle is based on the comparison of the conditions in a controlled transaction with the terms of the transaction between unrelated parties. Transactions are comparable if there is no difference between them or if the differences cannot significantly affect the transaction conditions (prices or margins). The aim of this analysis is to find comparable companies, i.e. transactions. A comparable uncontrolled transaction is considered to be a transaction that occurs between two independent parties and that is comparable to the controlled transaction under investigation.

Transactions are comparable when there is a similarity in one or more aspects: the subject of the transaction (e.g. the same or similar raw material is sold to unrelated parties); contractual terms (date of transaction, subject of contract, delivery terms, quantity discounts, rebates), economic or market conditions (comparable transactions take place in a similar market).

Internal or external comparable data can be sources of information for checking transfer prices. In the event that the taxpayer has purchased the same or similar product/ service from both related and unrelated persons in similar volumes, markets and conditions, this information can be used for checking transfer prices, as internally comparable data. When an unrelated person buys/sells a product/service in similar quantities, markets, and conditions, this information can be used as an external comparable data. The usual sources of externally comparable data are commercial databases (e.g. Amadeus Buerau Van Dijk, Orbis Buerau Van Dijk, Thomson Reuters).

Transactions with affiliates must be checked using one of the available transfer pricing methods (OECD, 2010). At the international level, taxpayers applying tax planning try to minimize the tax liability of the group by directing most of the taxable income to the state where the effective tax rate is the lowest. At the national level, taxpayers will direct most of the taxable income to the member of the group that has current or transferred tax losses from previous years or the ability to use tax incentives.

An analysis of comparable data and the application of appropriate methods will result in a range of the "arm's length" principle prices. The range is the result of the fact that independent companies do not necessarily have to establish the identical price at which the transaction is concluded. In cases where the range is established, the transfer price is deemed to be no different from the "arm's length" principle price if the transfer price is within that the range. If the transfer price is outside of the range, the "arm's length" principle price is equal to the median of the specified range.

When transfer pricing does not reflect market relations and the "arm's length" principle, there may be distortions regarding the tax liabilities of the related parties and the state's tax revenues. If revenue based on transfer pricing is lower than the income on the basis of market prices, the taxable income increases. If the expense based on transfer pricing is higher than the expenditure on the basis of market prices, the expenditure for tax purposes is reduced. 
A number of authors have addressed the lack of precision of international guidelines, some of which have been mentioned here. Also interesting are those who consider international guidelines to be too "soft" to prevent profit from moving out of the country, whether the focus is on calculating specific types of transactions ( $\mathrm{Li}$, 2012) or the method of "dividing profits" (Ron, 2012; Kroppen, Dawid \& Schmidtke, 2012). Some authors point out the high complexity of the guidelines, as well as the lack of comparable billing data, and suggest introducing some fixed, simpler parameters (Luckhaupt, Overesch, \& Schreiber, 2012).

For developing countries, right calculation is of particular importance, and to avoid the shortcomings of the guidelines, it is proposed to innovate and introduce an alternative method: the Apportionment Method (Ostwal, T. 2009; Jaiswal, 2017). This is due to the fact that comparability is a major component of transfer pricing, and parameter comparison is based on statistical instruments subject to variation. Therefore, the timing of the observation of the calculation parameters and the minimum sample size of comparable companies should be defined more precisely (Matavulj, 2019, p. 94).

All of the research mentioned was based on a critique of the guidelines and the need to improve them, due to the global tax redistribution between countries. However, the guidelines have not yet been changed, and developing countries continue to use them as a standard in their tax regulations. Thus, the complexity and imprecision in the calculation of this type of tax is still topical. No other similar studies addressing the hypothesis and calculation parameters set out in this paper were found.

\section{Research Design and Hypothesis}

The subject of the research presented in this paper is a concrete test of the application of international guidelines, if the TNM and Cost Plus methods are equally acceptable. The guidelines indicate that in this case, the Cost Plus method should be given priority. However, the guidelines do not state why this method is favored, or for whom - e affiliate or the tax administration.

The main hypothesis in this paper is that the guidelines imprecisely define the calculation parameters, so the Cost Plus method should not always be favored over the TNM method if both methods are equally acceptable. This is important because different tax rates would be obtained depending on the preferred method. Therefore, this assumption will be tested through simulated calculations using both methods, applying minimal variations in the two comparability components: the time dimension of the parameters and the sample size. The testing will be done on the example of a multinational company from one of the developed European countries, which has a related party in one of the developing countries in Europe. The test party is a related entity of a taxpayer of a developing country. Several calculation scenarios are given for case of the mentioned changes, which yield different tax amounts. If a developing country accepts (by including in national regulations) an international recommendation on the benefits of the Cost Plus method - in practice it will have accepted that it will in some cases charge a smaller tax. As a result, it will have also accepted the possibility of "moving profits" to another country, which it wants to avoid.

The structure of the paper follows this research assignment, first presenting the international methodology for calculating transfer prices, and then continuing to test 
multiple variants of calculation using the TNM and Cost Plus methods, with a discussion of the obtained results and discrepancies. Finally, recommendations are made to prevent tax evasion, which is particularly important in the case of developing countries.

\section{Methods for transfer pricing}

According to international guidelines (OECD, 2010; UN 2013), the method used to check transfer prices generally depends on the circumstances of the case. It is possible to use a combination of several methods when necessary. The choice of method depends on:

- The nature of the transaction (e.g. procurement/sale of goods, business services, leasing, borrowing, consulting services, etc.);

- Availability and reliability of data for analysis;

- Degree of comparability between transactions;

- The appropriateness of using financial data of unrelated parties for analysis;

- The nature and reliability of the assumptions.

Each selected method must be practically applicable and must have a reasonable assessment of the results in accordance with the "arm's length" principle.

The methods used to determine the price of the transaction under the "arm's length" principle are:

- The comparable market price method, which compares the price of a product or service in transactions between related parties with the price of a product or service in transactions between unrelated parties, where transactions are carried out under comparable circumstances.

- The resale price method, which is based on the price at which the product is sold to an unrelated person, which is reduced by a comparable gross margin to determine the "arm's length" price for the same product purchased from a related party.

- The cost method, increased by the usual earnings-costs from transaction costs (sale of goods or services) to which the gross margin is added, depending on the functions being performed, the risks that are being accepted and the property being used.

- The transactional net margin method, entails the comparison of the net profit margins that a taxpayer realizes in transactions with affiliated persons with the net profit margins realized in similar transactions with unrelated entities, or between unrelated entities.

- Profit sharing method, which is used if a specific analysis of transactions between related parties is difficult, i.e. when the activities of related persons are united, as well as in cases of the existence of a valuable or unique intellectual property, when it is impossible to find comparable data that would allow each of them to separately analyze the compliance of their transfer pricing with “arm's length" prices. 
Table 1: Comparative presentation of the methods for calculating transfer prices

\begin{tabular}{|c|c|c|c|c|}
\hline $\begin{array}{c}\text { Comparable } \\
\text { Uncontrolled Price } \\
\text { Method (CUP) }\end{array}$ & $\begin{array}{l}\text { Resale Price } \\
\text { Method }\end{array}$ & Cost Plus Method & $\begin{array}{l}\text { Transaction Net } \\
\text { Margin Method } \\
\text { (TNM) }\end{array}$ & $\begin{array}{l}\text { Transactional Profit } \\
\text { Split Method }\end{array}$ \\
\hline $\begin{array}{l}\text { Compares prices } \\
\text { of controlled } \\
\text { and uncontrolled } \\
\text { transactions, } \\
\text { in comparable } \\
\text { circumstances: } \\
\text { the similarity of } \\
\text { the subject of } \\
\text { the transaction, } \\
\text { contractual terms, } \\
\text { economic and market } \\
\text { conditions. }\end{array}$ & $\begin{array}{l}\text { The price at } \\
\text { which something } \\
\text { is sold to an } \\
\text { unrelated entity, } \\
\text { after deduction } \\
\text { for Gross Margin } \\
\text { (GM) } \\
\text { GM = (Sales } \\
\text { Revenue - Cost } \\
\text { of Goods Sold)/ } \\
\text { Sales Revenue } \\
* 100\end{array}$ & $\begin{array}{l}\text { The cost price } \\
\text { (CP) is equal to the } \\
\text { direct costs (e.g. } \\
\text { prepayment) and } \\
\text { indirect costs (e.g. } \\
\text { maintenance) related } \\
\text { to the transaction, } \\
\text { increased by GM } \\
\text { GM = (Sales } \\
\text { revenue - CP) / CP } \\
* 100\end{array}$ & $\begin{array}{l}\text { TNM = Net } \\
\text { Profit/ Operating } \\
\text { Income or } \\
\text { Operating } \\
\text { Expenses or } \\
\text { Business Assets } \\
\text { Net Profit = } \\
\text { Operating Income } \\
\text { - Operating } \\
\text { Expenses }\end{array}$ & $\begin{array}{l}\text { Operating profit, } \\
\text { excluding the cost } \\
\text { of income tax and } \\
\text { the financial costs } \\
\text { of a controlled } \\
\text { transaction, is } \\
\text { shared with related } \\
\text { parties participating } \\
\text { in that transaction. } \\
\text { Exceptionally, the } \\
\text { total profit can be } \\
\text { taken. }\end{array}$ \\
\hline
\end{tabular}

Source: Author processing, based on international guidelines OECD (2010) and UN (2013)

\section{Table 1a: A more detailed view of calculation formulas for TNM}

\begin{tabular}{|l|l|}
\hline $\begin{array}{l}\text { ROA } \text { - Return rate on assets (usually only tangible } \\
\text { assets) }\end{array}$ & $=$ Operating profit / Operating assets \\
\hline $\begin{array}{l}\text { ROCE }- \text { The rate of return on the invested capital (total } \\
\text { capital - cash - investments) }\end{array}$ & $=$ Operating profit / Engaged capital \\
\hline OM - Operating margin & $=$ Operating profit / Sales revenue \\
\hline ROTC - Return rate to total costs & $=$ Operating profit / Total costs \\
\hline Return rate on the cost of selling products sold & $=$ Gross profit / Cost of selling products sold \\
\hline Berry ratio & $=$ Gross profit / Operating costs \\
\hline
\end{tabular}

Source: Author processing, based on international guidelines OECD (2010) and UN (2013)

After selecting the method, it is necessary to select the tested side, define a sample of comparable companies and the time period in which the selected indicators are observed. Depending on the method chosen, it is essential to further find the necessary data for calculating the average margin of comparable companies in the external database, then the interquartile range (from the $1^{\text {st }}$ to $3^{\text {rd }}$ quartile) and the median sample, to determine whether the margin of the tested company is within the specified range between the $1^{\text {st }}$ and $3^{\text {rd }}$ quarters, or instead use the median sample for the calculation of the "price out of reach".

\section{Calculation of transfer prices in practice: The application of two methods and the change of comparable parameters}

Literature lists a number of dilemmas (OECD, 2010, paragraphs 3.2-3.59) regarding the justification and applicability of selected transfer pricing methods, but until they are verified using for a specific case, the conclusions can be interpreted in different 
ways. This is because there are theoretical criticisms of the application of this concept, as previously mentioned. We will test the reliability of transfer pricing when two methods are equally applicable. The treatment of the income to be taxed depends only on the estimate of the one who calculates the transfer pricing of the related entity and the extent of deviation from the comparable parameters.

According to the OECD Secretariat Note on Transfer Pricing Methods (Cooper, Fox, Loeprick \& Mohindra, 2016, p. 173), Table 2 lists the most common examples for selecting the appropriate method in practice. In the particular case, further below, the recommendation from the guidelines will be: if the two methods, TNM and Cost Plus, are equally applicable priority is given to the latter. It is not specified in the guidelines why advantage is given to this method, nor whom it is favorst - he related entity or the tax administration. These questions will be answered after simulated calculation applying both methods, using minimal variations in two components of comparability: the time range of parameters and the sample size.

\section{Table 2: Illustration of the most appropriate method selection in specific case circumstances}

\begin{tabular}{|l|l|l|}
\hline \multicolumn{1}{|c|}{ If... } & \multicolumn{1}{|c|}{...Can be applied } \\
\hline $\begin{array}{l}\text { If CUP and another method can be applied in an equally } \\
\text { reliable manner }\end{array}$ & - CUP & \\
\hline $\begin{array}{l}\text { When one party to the transaction performs } \\
\text { "benchmarkable" functions(e.g. manufacturing, } \\
\text { distribution, services for which comparable values exist) } \\
\text { and does not make any valuable, unique contribution } \\
\text { (in particular does not contribute a unique, valuable } \\
\text { intangible) }\end{array}$ & $\begin{array}{l}\text { - One sided method } \\
\text { (seller or purchaser): generally, } \\
\text { the one that has the less } \\
\text { complex functional analysis }\end{array}$ & \\
\hline $\begin{array}{l}\text { The tested party is the seller (e.g. contract } \\
\text { manufacturing or provision of services) }\end{array}$ & $\begin{array}{l}\text { - Cost Plus } \\
\text { - Cost-based TNM (i.e. net } \\
\text { profit / costs) } \\
\text { - Asset-based TNM (i.e. testing } \\
\text { net profit / assets) }\end{array}$ & $\begin{array}{l}\text { If Cost Plus and TNM can be } \\
\text { applied in an equally reliable } \\
\text { manner: Cost Plus }\end{array}$ \\
\hline $\begin{array}{l}\text { The tested party is the buyer (e.g. marketing/ } \\
\text { distribution) }\end{array}$ & $\begin{array}{l}\text { Resale price } \\
\text { Sales-based TNM (i.e. testing } \\
\text { net profit / sales) }\end{array}$ & $\begin{array}{l}\text { If resale price and TNM } \\
\text { can be applied in an equally } \\
\text { reliable manner: resale price }\end{array}$ \\
\hline $\begin{array}{l}\text { When each of the parties makes valuable, unique } \\
\text { contributions to the controlled transaction (e.g. } \\
\text { contributes valuable unique intangibles) }\end{array}$ & $\begin{array}{l}\text { Two-sided method } \\
\text { Transactional profit split }\end{array}$ & \\
\hline $\begin{array}{l}\text { Multinational companies retain the freedom to use } \\
\text { "other methods" not listed above, provided that they } \\
\text { satisfy the "arm's length" principle. In such cases, the } \\
\text { rejection of the above-described methods and selection } \\
\text { of an "other method" should be justified. }\end{array}$ & Other methods & \\
\hline
\end{tabular}

Source: Cooper, Fox, Loeprick \& Mohindra, 2016, p. 173

For simplification purposes, all the details of the analyzed case will not be shown below, as well as the differences in the tax treatments and administrations of the two countries - developed, in which the company's headquarters reside, and the less-developed, in which a related entity is registered. It is important to note that in our case, in both countries, the OECD's international guidelines are incorporated into national legislation, therefore the method of calculation is uniform. The main objective is to show differences in the tax base, if one or the other selected method is chosen and if only a small deviation in sample size and observation period is made when calculating transfer prices. 


\section{The basic setting in testing}

The ABC company is registered for the production of other plastics products, code 2229. This company, located in one of the developing countries in Europe, is entirely dependent on the parent company. ABC Group, located in one of the developed European countries. This dependence is reflected in the fact that $\mathrm{ABC}$ gets all its raw materials from $\mathrm{ABC}$ Group, as its affiliated entity, then produces products according to its orders and sells them again to that same related entity. Considering that in our case the taxpayer produces and sells goods to its related entity, it is possible to apply two methods: Cost Price Plus Gross Margin and Transaction Net Margin (TNM). The ROTC formula (operating profit / total costs) is used in this case to calculate TNM. Other methods are not applicable because there is no other internally comparable data that could be used to check the transactions, and the nature of taxpayer's activity is production for the parent company rather than the resale products or services.

Using relevant $\mathrm{ABC}$ data, the difference in results of both methods are analyzed, as is the further influence on the change in results, i.e. on the final correction of the tax base that is included in the $\mathrm{ABC}$ tax balance. The $\mathrm{ABC}$ company is a tested party in the organization chain of $\mathrm{ABC}$ Group because it is a resident of the country in which the tax balance is submitted and because it is the simplest case to test (OECD, 2010). Table 3 lists the basic $\mathrm{ABC}$ balance data used in the testing.

Table 3: Basic ABC statement for 2017 year

\begin{tabular}{|l|c|}
\hline \multicolumn{1}{|c|}{ Description } & ABC transfer price \\
\hline A. Revenues from sales & 3.080 mil EUR \\
\hline B. Total operating costs & 3.067 mil EUR \\
\hline B1. Direct costs of the products sold ${ }^{2}$ & 2.414 mil. EUR \\
\hline B2. Other operating costs & 0,653 mil EUR \\
\hline C. Operating profit (A-B) & 0,014 mil EUR \\
\hline D. TNM \% (C/B) & $0,45 \%$ \\
\hline E. GM $\%(\mathrm{~A}-\mathrm{B} 1) / \mathrm{B} 1$ & $27,58 \%$ \\
\hline
\end{tabular}

Source: Data taken from the ABC Income Statement from Orbis (2018)

Given that there are no transactions with independent entities that could be used for comparison, the external Orbis database (2018) was used to establish a sample of comparable companies. Parameters selected as the strategy for this research, which are in line with the type, size and status of $\mathrm{ABC}$, are:

- All active and independent companies (without related parties) engaged in the production of other plastic products, code 2229,

- All companies of these species located in Western and Eastern Europe,

- All companies that have generated revenues over 1mil. EUR,

- Data analysis for 4 years (2014-2017), used to obtain gross margin and transaction net margin, for use in the Cost Plus and Transaction Net Margin, as Operating Profit / Total Costs.

\footnotetext{
${ }^{2}$ The assumption is that the cost price is equal to direct costs.
} 
By analyzing external data, a sample of 7 comparable companies was obtained, which can be used to further test the ABC transfer pricing.

Starting from paragraphs 3.58 and 3.59 of the OECD Guidelines (2010), which draw attention to situations where different results are obtained by applying different methods, as well as paragraphs 3.2, 3.38 and 3.46, in which the significance of the quantity and quality of the samples is analyzed, using the particular data we checked 4 calculation scenarios for each of the methods:

- Scenario 1: 7 companies in the sample, 4 years of observation,

- Scenario 2: 7 companies in the sample, 3 years of observation,

- Scenario 3: 6 companies in the sample, 4 years of observation,

- Scenario 4: 6 companies in the sample, 3 years of observation.

The choice of scenario will depend on the interest of the state or company that has to pay the tax. Small adjustments in parameters will result in large differences in tax amounts. It is necessary to define the calculation rules more precisely, because it is possible to manipulate results through the amount of taxable income of the company and the amount of tax collected by the state. Further consequences are possible in the other state where the company's headquarters are seated, where there may be double taxation or avoidance of tax payments, but these aspects will not be addressed in this paper.

\section{Possible scenarios for both methods and discussion of the results}

As already mentioned, after choosing the method, comparable companies are selected, with the corresponding data for calculating the gross or net margin, depending on the chosen method. In our case, the average margins, inter-quartile ranges and medians will be calculated (tables 4-7, recapitulation in tables 8-9), in order to ultimately present the difference in revenue adjustments (table 10) and the conclusion which scenario is the best for the company and the tax administration.

Table 4 gives an overview of average gross margins and interquartile ranges with a median for samples of 7 companies and 6 companies, for a period of 4 years $(2014$ 2017), calculating the sales price using the Cost Plus method.

Table 4: Average gross margins and interquartile ranges for scenarios 1 and 3 $\%$ Gross margin of company $A B C=27,58 \%$

\begin{tabular}{|c|c|c|c|}
\hline \multicolumn{2}{|c|}{ Scenario 1 } & \multicolumn{2}{c|}{ Scenario 3} \\
\hline $\begin{array}{c}\text { Company average gross } \\
\text { margins, in \% }\end{array}$ & Interquartile range & $\begin{array}{c}\text { Company average gross } \\
\text { margins, in \% }\end{array}$ & Interquartile range \\
\hline $37.63 \%$ & & $37,63 \%$ & $23,14 \%$ \\
$97.68 \%$ & $23,14 \%$ & $97,68 \%$ & $27,53 \%$ \\
$116.51 \%$ & $30,89 \%$ & $62,73 \%$ & $44,46 \%$ (median) \\
$62.73 \%$ & $51,29 \%$ (median) & $51,29 \%$ & $59,87 \%$ \\
$51.29 \%$ & $80,20 \%$ & $23,14 \%$ & $97,68 \%$ \\
$23.14 \%$ & $116,51 \%$ & $24,16 \%$ & \\
$24.16 \%$ & & & \\
\hline
\end{tabular}

Source: Calculation by the author based on data from the Orbis database (2018) 
Scenario 1 ( 7 companies in the sample, 4 years of observation), the ABC gross margin rate is not in range, so the median of 51,29\% would be used. In Scenario 3 (6 companies in the sample, the same observation period), the situation is different. The third company from the sample, with a gross margin of $116,51 \%$, was eliminated, so the $\mathrm{ABC}$ gross margin of $27,58 \%$ fell into the interquartile range. This means it will be used to calculate the selling price. Differences in the applied gross margin rate, using the Cost Plus method, with a change of only 1 company in the sample, will also affect the differences in the amount of revenue (Table 10, revenue for scenarios 1 and 3). Table 10 eventually analyzes the differences across all scenarios and methods, the parameters of which are presented in the following tables.

In Table 5, the TNM rate was tested for samples of 7 and 6 companies for a period of 4 years (2014-2017), at the rate of TNM of $\mathrm{ABC}=0,45 \%$

Table 5: Average TNMs and interquartile ranges for scenarios 1 and 3

$\%$ TNM of company $A B C=0,45 \%$

\begin{tabular}{|c|c|c|r|}
\hline \multicolumn{2}{|c|}{ Scenario 1 } & \multicolumn{2}{|c|}{ Scenario 3 } \\
\hline Company average TNM, in $\%$ & Interquartile range & Company average TNM, in $\%$ & Interquartile range \\
\hline $12,24 \%$ & & $12,24 \%$ & $1,47 \%$ \\
$6,10 \%$ & $1,47 \%$ & $6,10 \%$ & $3,55 \%$ \\
$13,07 \%$ & $3,56 \%$ & $12,71 \%$ & $4,83 \%$ (median) \\
$12,71 \%$ & $6,10 \%$ (median) & $1,47 \%$ & $10,71 \%$ \\
$1,47 \%$ & $12,47 \%$ & $3,56 \%$ & $12,71 \%$ \\
$3,56 \%$ & $13,07 \%$ & $3,55 \%$ & \\
$3,55 \%$ & & & \\
\hline
\end{tabular}

Source: Calculation by the author based on the data from the Orbis database (2018)

In the case of the TNM method, in Scenario 1 , the ABC TNM rate $(0,45 \%)$ is not in range, so the median that is used is $6,10 \%$. Also in Scenario 3, the ABC TNM rate is not in range, but the median that is used is $4,83 \%$. As in the previous case, the amount of taxable income would change depending on the scenarios and methods chosen, which is presented in greater detail in Table 10.

When reducing the number of years in the observation period from 4 to 3 , i.e. the sample of 7 and 6 companies during the period 2015-2017, the test results for both methods are shown in tables 6 and 7.

Table 6: Average gross margins and interquartile ranges for scenarios 2 and 4 $\%$ Gross margin of $A B C=27,58 \%$

\begin{tabular}{|c|c|c|r|}
\hline \multicolumn{2}{|c|}{ Scenario 2} & \multicolumn{2}{c|}{ Scenario 4 } \\
\hline $\begin{array}{c}\text { Company average gross } \\
\text { margins, in \% }\end{array}$ & $\begin{array}{c}\text { Interquartile } \\
\text { range }\end{array}$ & $\begin{array}{c}\text { Company average gross } \\
\text { margins, in \% }\end{array}$ & Interquartile range \\
\hline $38,68 \%$ & & $38,68 \%$ & $25,03 \%$ \\
$92,55 \%$ & $25,03 \%$ & $92,58 \%$ & $28,55 \%$ \\
\cline { 2 - 4 } $120,65 \%$ & $31,93 \%$ & $65,08 \%$ & \\
\hline
\end{tabular}




\begin{tabular}{|r|c|c|r|}
$65,08 \%$ & $58,01 \%$ (median) & $58,01 \%$ & $48,35 \%$ (median) \\
$58,01 \%$ & $78,81 \%$ & $25,17 \%$ & $63,31 \%$ \\
$25,17 \%$ & $120,65 \%$ & $25,03 \%$ & $25,03 \%$ \\
$25,03 \%$ & & & \\
\hline
\end{tabular}

Source: Calculation by the author based on the data from the Orbis database (2018)

In Scenario 2 (7 companies in the sample, 3 years of observation), using the Cost Plus method, and the ABC gross margin rate of $27,58 \%$, the median used is $58,01 \%$. In Scenario 4 , the third company from the sample, with a gross margin of $120,65 \%$, was eliminated. Because the ABC gross margin is out of margin range, the median of $48,35 \%$ is used in the calculation. In both scenarios, the result of the calculation is different, as is the taxable income.

Table 7: Average TNMs and interquartile ranges for scenarios 2 and 4 $\%$ TNM of company $A B C=0,45 \%$

\begin{tabular}{|c|c|c|c|}
\hline \multicolumn{2}{|c|}{ Scenario 2} & \multicolumn{2}{c|}{ Scenario 4} \\
\hline $\begin{array}{c}\text { Company average TNM, } \\
\text { in } \%\end{array}$ & Interquartile range & $\begin{array}{c}\text { Company average TNM, } \\
\text { in } \%\end{array}$ & Interquartile range \\
\hline $12,29 \%$ & & $12,29 \%$ & \\
$5,70 \%$ & $3,31 \%$ & $5,70 \%$ & $3,31 \%$ \\
$13,01 \%$ & $4,22 \%$ & $13,79 \%$ & $4,06 \%$ \\
$13,79 \%$ & $5,70 \%($ median) & $3,31 \%$ & $5,12 \%$ \\
$3,31 \%$ & $12,65 \%$ & $4,55 \%$ & $10,64 \%$ \\
$4,55 \%$ & $13,79 \%$ & $3,89 \%$ & $13,79 \%$ \\
$3,89 \%$ & & & \\
\hline
\end{tabular}

Source: Calculation by the author based on the data from the Orbis database (2018).

In Scenario 2, using the TNM method, the ABC TNM rate of $0,45 \%$ is not within range, so the median of $5,70 \%$ is used. In Scenario 4, the ABC TNM rate is not within range too, but the median of $5,12 \%$ is used.

Tables 8 and 9 recapitulate all scenarios, first for the Cost Plus method (Table 8) and then for the TNM method (Table 9). All the rates shown below are used in specific calculations of taxable income using one method or the other.

Table 8: Recapitulation of the market range - transaction net margins $\%$ TNM of company $A B C=0,45 \%$

\begin{tabular}{|l|c|c|c|}
\hline $\begin{array}{c}\text { Number of companies in the sample/ } \\
\text { number of years }\end{array}$ & The first Quarter & Median & Third Quarter \\
\hline 6 firms/3 years - Scenario 4 & $4,06 \%$ & $5,12 \%$ & $10,64 \%$ \\
\hline 6 companies/4 years - Scenario 3 & $3,55 \%$ & $4,83 \%$ & $10,71 \%$ \\
\hline 7 firms/3 years - Scenario 2 & $4,22 \%$ & $5,70 \%$ & $12,65 \%$ \\
\hline 7 companies/4 years -Scenario 1 & $3,56 \%$ & $6,10 \%$ & $12,47 \%$ \\
\hline
\end{tabular}

Source: Autor, data from tables 5 and 7 
Table 8 shows that the ABC TNM rate is out of range in all scenarios, so the median that is used depends on the selected scenario.

\section{Table 9: Recapitulation of the market range - of gross margin $\%$ Gross margin of company $A B C=27,58 \%$}

\begin{tabular}{|l|r|r|r|}
\hline \multicolumn{1}{|c|}{$\begin{array}{c}\text { Number of companies in the sample/number } \\
\text { of years }\end{array}$} & \multicolumn{1}{|c|}{ The first Quarter } & \multicolumn{1}{c|}{ Median } & Third Quarter \\
\hline 6 firms/3 years - Scenario 4 & $28,55 \%$ & $48,35 \%$ & $63,31 \%$ \\
\hline 6 companies/4 years - Scenario 3 & $27,53 \%$ & $44,46 \%$ & $59,87 \%$ \\
\hline 7 firms/3 years - Scenario2 & $31,93 \%$ & $58,01 \%$ & $78,81 \%$ \\
\hline 7 companies/4 years -Scenario 1 & $30,89 \%$ & $51,29 \%$ & $80,20 \%$ \\
\hline
\end{tabular}

Source: Autor, data from tables 4 and 6

Table 9 shows that only in Scenario 3, the ABC gross margin is within the given range of the average market margins, while in the other cases, for different median is used revenue calculation, depending on the selected scenario. In this situation, using the Cost Plus method, the ABC revenue for transfer prices will be 3.080 mil. EUR, (indicated in yellow in Table 10). Only in this case (sample of 6 companies and 4 years of observation) should the income adjustment not be the basis for taxation.

Table 10 shows revenues at "arm's length" principle prices for both methods, depending on scenario is used for comparative analysis. It also shows the correction of revenues, which represents a correction of the tax base.

Table 10: Correction of revenue for TNM and Cost Plus methods, for 4 scenarios In mil. EUR

\begin{tabular}{|c|c|c|c|c|}
\hline Scenarios & $\begin{array}{c}\text { Revenue "arm's } \\
\text { length" principle by } \\
\text { TNM method }\end{array}$ & $\begin{array}{c}\text { Revenue "arm's length" } \\
\text { principle by the Cost } \\
\text { Plus method }\end{array}$ & $\begin{array}{c}\text { Correction of } \\
\text { revenue by TNM } \\
\text { method }\end{array}$ & $\begin{array}{c}\text { Correction of } \\
\text { revenue by Cost Plus } \\
\text { method }\end{array}$ \\
\hline 1 & 3.254 & 3.652 & 0,174 & 0,572 \\
\hline 2 & 3.242 & 3.814 & 0,161 & 0,734 \\
\hline 3 & 3.215 & 3.080 & 0,134 & 0 \\
\hline 4 & 3.224 & 3.581 & 0,143 & 0,501 \\
\hline
\end{tabular}

Source: Calculation by the author, using data from tables 1, 8 and 9.

Bearing in mind the differences shown in the corrections by both methods, for the ABC company it is most beneficial to use Scenario 3 (a sample of 6 companies and 4 years of observation), because then it will not have to correct the tax base. From the aspect of the tax administration, the most favorable scenario would be Scenario 2 (7 companies, 3 years of observation) because the ABC company would then have to correct the tax base by EUR 734.000 and thus pay a higher tax.

On the other hand, according to the OECD guidelines both methods are applicable, but the Cost Plus method is preferred. It is evident that Cost Plus will not be applied in every scenario. The difference in the corrections by both methods, for each of the four scenarios in the analyzed example, ranges from a minimum of EUR 134.000 (for 
Scenario 3, correction of revenue by TNM method) to a maximum of EUR 572.000 (for

Scenario 1, correction of revenue using the Cost Plus method).

From previous calculations using both methods, with different parameters within the sample size and length of the observation period, the following can be concluded:

- It is significant which method, as well as the size of the sample and the period of observation for comparable companies, will be applied, because they all directly influence the amount of taxable company income.

- When both methods are applicable, should not favor the Cost Plus method, since possible variations in the comparability parameters are not taken into account.

- Using the Cost Plus method, when decreasing the number of years, the median or interquartile range also changes, with the median increasing slightly and the range expanding, while the $\mathrm{ABC}$ gross margin is within the range limits in both scenarios. By decreasing the number of years, the company's gross margin would be used and there would be no correction of the tax base. On the other hand, by reducing the number of companies in the sample by only one company, there is a change in the use of the gross margin rate, whereby for the smaller sample of companies the $\mathrm{ABC}$ gross margin rate can be used and in all other scenarios the median used, creating a higher ABC taxable income.

- If the TNM method is used, in all the considered scenarios, the ABC TNM rate would not be used because it is always outside of the ranges. Instead, it is necessary to use the median, which varies depending on the size of the sample and the length of the observation period. This indicates that there will certainly be a correction of the tax base, but how much $\mathrm{ABC}$ will have to pay in additionally will depend on the choice of the median.

\section{Conclusion}

According to international guidelines for the calculation of transfer pricing of related entities, all methods are equal and the choice of one of them is made depending on the circumstances of the particular case. It is also recommended that if in some cases two methods are acceptable, e.g. the Transaction Net Margin and Cost Plus method, priority is given to the Cost Plus method. However, it is not specified from which aspect this method is prefers, and whether this recommendation is valid even if two important comparison components are changed: the time dimension of parameters observation for calculation and the size of the sample of comparable companies. It is very important from which aspect the calculation is managed, especially in the case of developing countries. If the aspect of the company is favored, since it is obliged to attach a tax return to the balance sheet, then the best option is the one in which the company will pay the lowest tax. However, if the tax authority has the right to request a change in the calculation, then it will look at it from the standpoint of the state interest, and the most unfavorable option for the company can be applied.

The scenarios in the tested case showed that internationally recognized recommendations on the selection of methods have weaknesses because they do not include all the parameters of the methodology itself, which significantly affects the end 
result. In a situation where the time period of observation is flexible and the minimum size of the sample of comparable companies does not exist, there is a plenty of room for manipulating the end result. There are many objections in literature to the concept of transfer pricing, but no practical examples and studies similar to the calculations outlined in this paper are available to confirm deviations.

The main hypothesis in this paper was confirmed: the Cost Plus method should not always take precedence over the TNM method. It is evident that OECD guidelines are not always applicable in practice. In the case tested in the paper, the difference in the corrections by both methods, for each of the four scenarios, ranged from a minimum of EUR 134.000 (for Scenario 3: correction of revenue using the TNM method) to a maximum of EUR 572.000 (for Scenario 1: correction of revenue using the Cost Plus method). For the tested company it is most beneficial to use Scenario 3 (a sample of 6 companies and 4 years of observation). From the aspect of the tax administration, the most favorable scenario would be Scenario 2 (7 companies, 3 years of observation). Using the Cost Plus method, when decreasing number of years, there will be no correction the tax base. On the other hand, by reducing the number of companies in the sample by only one company, there is a great change in the taxable income. If the TNM method is used, all considered scenarios require corrections of the tax base.

In order to avoid ambiguity and various forms of manipulation in the transfer pricing calculation, it is necessary to specify the international guidelines in the domain of time dimension and size of the sample. Additionally, the taxpayer's obligation to introduce transfer price calculations should be introduced for all methods that correspond to the circumstances of their case, and not just one of them. In this case, it should be defined whether it is acceptable to apply the most favorable option for the company (but not for the state), for the state (but not for the company) or perhaps some middle variant that would result from the tests performed on all parameters. This can be overcome either by changing the guidelines or by defining rules in greater detail at the level of the national legislation of each state, whilst improving the professional capacity of the tax administration to control transfer pricing.

\section{References}

Bhata, G. (2009). Transfer Pricing, Tax Havens and Global Governance. Discussion Paper/Deutsches Institut für Entwicklungspolitik, Bonn. ISBN 978-3-88985-455-1

Cooper, J., Fox, R., Loeprick, J., \& Mohindra, K. (2016). Transfer Pricing and Developing Economies: A Handbook for Policy Makers and Practitioners. Washington, DC: World Bank.

De Robertis, G. (2018). The end of the arm's-length principle? What to Tax? Perspectives on tax are changing. Tax is changing perspectives. (pp. 14-17). KPMG International. Retrieved August 13, 2019 https://responsibletax.kpmg. com/page/the-end-of-the-arm-s-length-principle-

Durst, C.M. (2010). It's Not Just Academic: The OECD Should ReevaluateTransfer Pricing Laws. Tax Analysts, January 18, 2010. (pp. 247-256). Retrieved August 12, 2019, from https://www.taxjustice.net/cms/upload/pdf/Durst_1001_OECD__not_just_academic. pdf 
Durst, C.M. (2010a). Making Transfer Pricing Work for Developing Countriesby. Tax Analysts, December 13, 2010. (pp. 851-854). Retrieved August 12, 2019, from https:/www.taxjustice.net/wp-content/uploads/2013/04/Durst_2010_developing _ countries.pdf

Elliot, J, \& Emmanuel, C. (2002). International Transfer Pricing. In Lymer, A., \& Hasseldine, J. (Eds.), The International Taxation System. Kluwer Academic Publishers, Dordrecht. 157 at 158.

Jaiswal, S. (2017). A Primer on Transfer Pricing: Norms, Standards, Misuse for Tax Avoidance and Impacts on Developing Countries, Centre for Budget and Governance Accountability (CBGA). New Delhi.

Jovanović, T. (2018). Kvalitet izveštavanja o transfernim cenama - pretpostavka kvaliteta poreskog izveštavanja povezanih lica. Anali Ekonomskog fakulteta u Subotici, (39) (str. 305-327).

Kroppen H-K., Dawid, R., \& Schmidtke, R. (2012). Profit Split, the Future of Transfer Pricing? Arm's Length Principle and Formulary Apportionment Revisited from a Theoretical and a Practical Perspective. In Schön, W., \& Kai A. K. (Eds.), Fundamentals of International Transfer Pricing in Law and Economics: MPI Studies in Tax Law and Public Finance 1 (pp. 267-293). Germany: SpringerVerlag Berlin Heidelberg. DOI 10.1007/978-3-642-25980-7. Retrieved August 20, 2019, from https://link.springer.com/chapter/10.1007/978-3-642-25980-7_5

Li, J. (2012). Soft Law, Hard Realities and Pragmatic Suggestions: Critiquing the OECD Transfer Prices Guidelines. In Schön, W., \& Kai A. K. (Eds.), Fundamentals of International Transfer Pricing in Law and Economics: MPI Studies in Tax Law and Public Finance 1 (pp. 71-87). Germany: Springer-Verlag Berlin Heidelberg. DOI 10.1007/978-3-642-25980-7. Retrieved August 20, 2019, from https://link. springer.com/chapter/10.1007/978-3-642-25980-7_5

Luckhaupt, H., Overesch, M., \& Schreiber, U. (2012). The OECD Approach to Transfer Pricing: A Critical Assessment and Proposal. In Schön, W., \& Kai A. K. (Eds.), Fundamentals of International Transfer Pricing in Law and Economics: MPI Studies in Tax Law and Public Finance 1 (pp. 91-121). Germany: SpringerVerlag Berlin Heidelberg. DOI 10.1007/978-3-642-25980-7. Retrieved August 20, 2019, from https://link.springer.com/chapter/10.1007/978-3-642-25980-7_5

Matavulj, Lj. (2019). Transferne cene - izazovi primene u praksi. Zbornik radova, Knjiga II, sa VI Medjunarodne konferencije LEMiMA - Pravo, ekonomija i menadžment u savremenim uslovima (str. 83-95). Beograd: Fakultet za poslovne studije i pravo i Fakultet za informacione tehnologije i inženjerstvo.

OECD. (2011). OECD Paper: Transfer Pricing Legislation - A suggested approach, June 2011. Retrieved August 10, 2019, from http://www.oecd.org/ctp/transferpricing/45765682.pdf.

OECD. (2010). OECD Transfer Pricing Guidelines for Multinational Enterprises and Tax Administrations. Retrieved August 10, 2019, from www.oecd.org/ctp/tp/cpm

ORBIS Database. (2018). Retrieved December 11, 2018 from https://orbis.bvdinfo. com/version-2019314/home.serv?product $=$ OrbisNeo. 
Ostwal, T. (2009). Tax Justice Transfer Pricing in Developing Countries - An Introduction.Network. Retrieved August 23, 2019, from https://www.taxjustice. net/wp- content/uploads/2013/04/TP_in_developing_countries.pdf

Ron, J. (2012). Transfer Pricing in the Courts: A Cross-Country Comparison. In Schön, W., \& Kai A. K. (Eds.), Fundamentals of International Transfer Pricing in Law and Economics: MPI Studies in Tax Law and Public Finance 1 (pp. 185-244). Germany: Springer-Verlag Berlin Heidelberg. DOI 10.1007/9783-642-25980-7. Retrieved August 20, 2019, from https://link.springer.com/ chapter/10.1007/978-3-642-25980-7_5

Sikka, P. (2009). Shifting profits across borders". The Guardian. Retrieved 27. February 2017. https://www.theguardian.com/commentisfree/2009/feb/11/ taxavoidance-tax

Sikka, P. \& Willmott, H. (2010). The dark side of transfer pricing: Its role in tax avoidance and wealth retentiveness. Critical Perspectives on Accounting, 21(4), pp. 342-356.

Timms, D. (2013). The harmonisation of transfer pricing: The obstacles, the arm's length principle and the OECD guidelines, LLM Research Paperlaws 516: Taxation. Faculty of law, Victoria, University of Wellington. Retrieved August 25, 2019, from http://researcharchive.vuw.ac.nz/bitstream/handle/10063/3186/ thesis.pdf? sequence $=1$

UN. (2013). United Nations Practical Manual on Transfer Pricing for Developing Countries. New York: UN. Retrieved August 10, 2019, from https://www.un.org/ esa/ffd/wp-content/uploads/2014/08/UN_Manual_TransferPricing.pdf

UNCTAD. (2015). World Investment Report 2015: Reforming International Investment Governance. (pp. 198-206). Retrieved August 11, 2019, from https:// unctad.org/en/PublicationsLibrary/wir2015_en.pdf

UN. (2017). Practical Manual on Transfer Pricing for Developing Countries. 2nd ed. United Nations. Retrieved August 11, 2019, from https://www.un.org/esa/ffd/ wp-content/uploads/2017/04/Manual-TP-2017.pdf 